\title{
Severe traumatic dental injuries and oral health related quality of life of preschool children
}

\author{
Traumatismos dentários severos e qualidade de vida relacionada \\ à saúde bucal de crianças pré-escolares
}

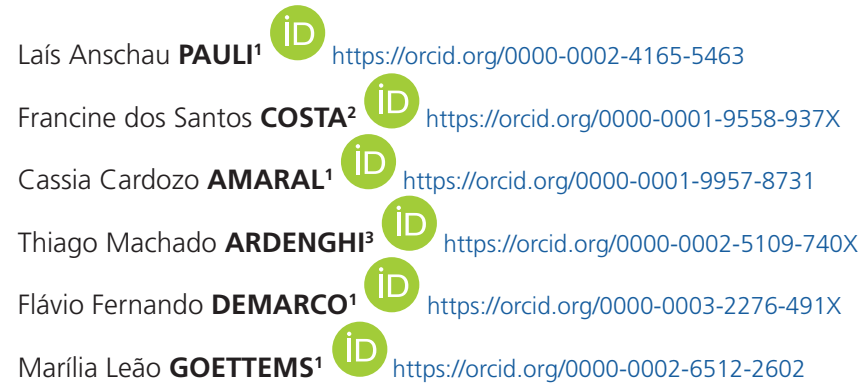

\section{ABSTRACT}

Objective: The aim of this study was to investigate the impact of severe traumatic dental injuries on the Oral Health related Quality of Life (OHRQoL) of preschool children. Methods: This cross-sectional study was conducted with children aged 2 to 5 years and their mothers, in Pelotas/ Brazil Southern. The Early Childhood Oral Health Impact Scale (ECOHIS) was applied to assess the perception of mothers about children's OHRQoL. Oral examination included dental trauma, categorized as absent/mild (enamel fracture only) or severe, the number of decayed, missing or restored primary teeth (dmft), and presence of anterior open bite. The impact of severe dental trauma on OHRQoL was evaluated using logistic regression analysis $(P<0.05)$. Results: A total of 599 preschool children were included and $7.4 \%$ had severe dental trauma. Of these $73.3 \%$ showed negative impact on OHRQoL ( $p=0.044)$. After adjustments, children with severe dental trauma had an impact in OHRQoL 110\% higher than those without/with mild trauma (OR: 2.10, 95\% CI 1.01-4.35). Severe dental injuries caused negative impact on the oral symptoms (OR: 2.13,95\% CI 1.10-4.14), psychological (OR: 2.13, $95 \% \mathrm{Cl} 1.10-4.13$ ) and family function (OR: 2.79, 95\% Cl 1.17-6.61) domains. Conclusion: The presence of severe dental trauma impacts the OHRQoL of preschool children and their families.

Indexing terms: Child preschool. Quality of life. Tooth injuries.

\section{RESUMO}

Objetivo: O objetivo deste estudo foi investigar o impacto de lesões dentais traumáticas severas na Qualidade de Vida Relacionada à Saúde Bucal (QVRSB) de crianças pré-escolares. Métodos: Estudo transversal realizado com crianças de 2 a 5 anos e suas mães,

\footnotetext{
1 Universidade Federal de Pelotas, Faculdade de Odontologia, Programa de Pós-Graduação em Odontologia. Rua Gonçalves Chaves, 457, Centro, 96015-560, Pelotas, RS, Brasil. Correspondence to: LA PAULI. E-mail: <laisanschaupauli@hotmail.com>.

2 Universidade do Vale do Taquari, Centro de Ciências Biológicas e da Saúde. Lajeado, RS, Brasil.

3 Universidade Federal de Santa Maria, Faculdade de Odontologia, Programa de Pós-Graduação em Ciências Odontológicas. Santa Maria, RS, Brasil.

$\boldsymbol{v} \nabla \boldsymbol{v}$

How to cite this article

Pauli LA, Costa FS, Amaral CC, Ardenghi TM, Demarco FF, Goettems ML. Severe dental trauma and quality of life. RGO, Rev Gaúch Odontol. 2020;68:e20200048. http://dx.doi.org/10.1590/1981-863720200004820190044
} 
na cidade de Pelotas / RS. A escala Early Childhood Oral Health Impact Scale (ECOHIS) foi aplicada para avaliar a percepção das mães sobre a QVRSB das crianças. O exame de saúde bucal incluiu traumatismo dentário, classificado como ausente / leve (fratura de esmalte apenas) ou severo, o número de dentes decíduos cariados, ausentes ou restaurados (ceo-d) e a presença de mordida aberta anterior. O impacto do traumatismo dentário severo na QVRSB foi avaliado por meio de análise de regressão logística $(P<0,05)$. Resultados: Foram incluídos 599 pré-escolares e 7,4\% sofreram traumatismo dentário severo. Destes, 73,3\% apresentaram impacto negativo na QVRSB $(p=0,044)$. Após ajustes, as crianças com traumatismo dentário severo tiveram um impacto na QVRSB $110 \%$ maior do que aquelas sem trauma / com trauma leve (OR: 2,10, IC 95\% 1,01-4,35). Traumas dentais graves causaram impacto negativo nos domínios sintomas orais (OR: 2,13, IC 95\% 1,10-4,14), domínio psicológico (OR: 2,13, IC 95\% 1,10-4,13) e função familiar (OR: 2,79, IC 95\% 1,17-6,61). Conclusão: A presença de traumatismo dentário severo impacta a QVRSB de crianças pré-escolares e suas famílias.

Termos de indexação: Pré-escolar. Qualidade de vida. Traumatismos dentários.

\section{INTRODUCTION}

Traumatic dental injuries (TDI) are the second most frequent reason for pediatric dental consultation, after dental caries. During early life, children are particularly vulnerable to these injuries [1] and the occurrence of TDI may result in pain, aesthetic and functional dysfunctions, with possible psychological repercussions [2]. However, the impact of TDI in primary dentition on children oral healthrelated quality of life is controversial. Whereas some studies have found that children presenting TDI had impaired oral health-related quality of life (OHRQoL) [3-5], and that TDI can cause a negative impact on the family function, including work absenteeism by parents [4], other studies have showed that the presence of this condition does not impair OHRQoL [6-8]. The possible impact on OHRQoL is an important indicator to define priorities in public health. Thus, it is important to evaluate factors associated with oral health perception.

A recent study has showed that enamel fracture does not impact on OHRQoL [9]. While enamel fracture is the most common injury, it may go unnoticed, unlike more severe injuries that require treatment or followup examinations [10]. Viegas et al. [11] found that the OHRQoL of the children and their families was influenced by the parental report of the occurrence of TDI, but not by the presence of TDI detected in clinical examination, assessed using Andreasen criteria. The study of Abanto et al. [12] showed that TDI, diagnosed using Glendor criteria, caused impact on some items of the family impact scale. The authors also detect that children with complicated injuries presented higher scores on OHRQoL than children with uncomplicated injuries or no injury. Kramer et al. [2] adopted Andreasen criteria to diagnose dental trauma and found that children with the presence of at least one type of trauma presented higher impact on OHRQoL. Thus, results vary according to the population studied, the criteria used to diagnose TDI and the level of severity of the injuries included

Since traumatic dental injuries can range from enamel fracture only to tooth loss, severity of the injury should be taken into account while evaluating the possible consequences of dental trauma. This study aimed to investigate the impact of TDI on the OHRQoL of children and family. The hypothesis was that the presence of severe dental trauma produces a significant negative impact on oral health-related quality of life of the child and family.

\section{METHODS}

\section{Subjects and study design}

This cross-sectional study was approved by the Human Research Ethics Committee of the University of Pelotas. An epidemiological survey was conducted with children at 2 to 5 years-old and their mothers, during the Day of the Children National Vaccination Campaign. According to the Ministry of Health, acceptance of the program in Pelotas was $90 \%$ among children up to 59 months. Of these children, only a small percentage (4\%) was vaccinated in other places than public health centers. A two-stage sampling procedure was adopted in order to ensure representativeness of the sample. Using a probability selection method, with probability proportional to the size of the Basic Health Units (BHU), nine BHU were randomly selected out of 25 existing in town that have dental office, from the relation obtained from the Municipal Health, considering the expected attendance of children at each site. In each of the seven administrative areas in which the city is divided there was at least one sampling point. Only $\mathrm{BHU}$ located in the urban area of Pelotas and equipped with dental offices were included. 
For the present study, a minimum sample size of 293 children was estimated, in line with an estimated prevalence of impact in OHRQoL of 7.4\% [2], a margin of error of 3 percentual points, and a confidence level of $95 \%$. To cover non-response, the sample was increased by $20 \%$ to 391 mother-child dyads.

\section{Data collection}

Data were collected through clinical examinations and interviews by 12 examiners, graduate dental students, and 35 assistants. The data collection consisted of interview and oral health exam of child. Previously to conducting the survey, a pilot study with 13 children was conducted to test the operability of the proposed methodology.

After the child had been vaccinated, mothers were invited to participate in the survey. All mothers signed an informed consent form and answered a questionnaire that included demographic and socioeconomic information. The outcome was assessed by Brazilian version of Early Childhood Oral Health Impact Scale (ECOHIS) $[13,14]$, applied to the mothers to evaluate their perception about OHRQoL. The instrument consists of 13 questions, including a child impact section (symptoms, function, psychological, self-image/social interaction domains) and a family impact section (parent distress and family function domains). Answers were recorded using a Likert scale, with response options coded from 0 to $5(0=$ never, $1=$ hardly ever, 2 = occasionally, 3 = often, $4=$ very often, and $5=$ do not know). To those who responded "do not know" in up to 2 items in the child section and 1 in the family, a score for the missing values was obtained from the average of the issues section [15]. The total score is obtained through the sum of scores and can range 0-52. Impact was considered present when ECOHIS was $\geq 1$. Also, the prevalence, intensity and extent of impacts were evaluated. The prevalence of impact refers to the proportion of subjects that reported 'hardly ever', 'occasionally', 'often' and 'very often' for at least one daily life performance. The extent was considered the number of performances (items of questionnaire) affected. The intensity of the impacts referred to the highest score reported by the mother for the 13 items and was used to classify subjects into groups.

The oral examination of the child was performed in the dental office under artificial light, using wooden spatula, gauze, mirror and CPI probe and following the precepts of biosecurity [16]. Children who did not allow oral examination were excluded from the study. The mothers were informed about the oral health status of children and those who sought treatment were included in the University Pediatric Clinic as needed.

The maxillary anterior teeth were evaluated for the presence and degree of traumatism [17]. The type of trauma was categorized as mild trauma, when limited to the enamel and not requiring restorative treatment, and as severe trauma, when involving at least the dentin [18]. The condition of the crown was evaluated by the WHO dmft (number of decayed primary teeth, missing or restored), each component being tracked individually [16]. The presence of anterior open bite was also evaluated [19].

The child's age (24-35, 36-47 or $\geq 48$ months), family income (tertiles) and maternal education ( $>8$ or $\leq$ 8 years) and dental caries and maloclusion were collected and used as control confounders.

\section{Training and calibration}

Interviewers were previously trained, and examiners received theoretical training and underwent a process of calibration with 20 children, previously selected to present different types of dental trauma. The first stage consisted of a 4-hours theoretical training, about the interview and clinical examination. In the second stage, examiners proceeded to the oral clinical examination of 15 children at the Clinic of Pediatric Dentistry, Faculty of Dentistry, Federal University of Pelotas. The inter-examiner agreement ranged from 0.70 to 1 for occlusion, 0.70 to 0.93 for dental trauma and 0.85 to 0.96 for caries. Intraexaminer agreement, calculated from the re-examination of the children after one-week interval, was 1 to occlusion and ranged from 0.70 to 1 for trauma and caries.

\section{Statistical analysis}

Data were analyzed using the software Stata 12.0 (Stata Corporation, College Station, USA). Initially, descriptive analysis of the data was taken. Chi-squared test was used to compare the prevalence of impact in children with mild/absent dental trauma and children with severe dental trauma. The impact of the independent variables on overall and domain-specific scores ECOHIS was evaluated using logistic regression analysis (Odds Ratio; 95\% Confidence Interval). Multiple linear regression 
models using 'forward stepwise' entry procedures were used to assess the independent effects of variables on ECOHIS scores. All variables derived from the clinical examination and interview were used in the regression analyses as confounders. For multiple regression analysis, all the variables in the bivariate analysis with $p \leq 0.20$ were included in the construction of model. A significance level of $5 \%$ was adopted.

\section{RESULTS}

A total of 599 preschool children were included. Table 1 shows characteristics of the sample. It was observed that $50.7 \%$ were girls, $45.5 \%$ of families were in first tertile of income and $60.9 \%$ were caries free. A total of 176 children (29.4\%) had dental trauma: 131 $(21.9 \%)$ presented with enamel fracture only, 11 (1.8\%) with enamel and dentine fracture, $11(1.8 \%)$ with fracture with pulp involvement, $15(2.5 \%)$ presented signs of discoloration and/or fistula and 8 (1.3\%) suffered avulsion.

A total of $57.2 \%$ of the children without dental trauma or with mild injuries and $73.3 \%$ of the children with severe dental trauma showed a negative impact on oral health-related quality of life $(p=0.044)$. Also, the dental trauma in preschool children was statistically associated with the following domains of the ECOHIS: oral symptoms, in the child section, and family function and parent distress, in the family section (table 2).

In analysis of extension and intensity (table 3), no statistically difference was observed in extension of impact and intensity when compared children with or without severe dental trauma. Concerning prevalence of impact on OHRQoL the results were statistically significant $(p=0.041)$.
Table 1. Socioeconomic, demographic and clinical characteristics of the sample. Pelotas, Brazil $(n=599)$.

\begin{tabular}{|c|c|c|c|}
\hline Variables & Categories & $n$ & $\%$ \\
\hline \multicolumn{4}{|l|}{ Sex } \\
\hline & Male & 295 & 49.3 \\
\hline & Female & 304 & 50.7 \\
\hline \multicolumn{4}{|c|}{ Age (months) } \\
\hline & $24-35$ & 171 & 28.5 \\
\hline & $36-47$ & 183 & 30.5 \\
\hline & $48-53$ & 197 & 32.9 \\
\hline & 54 & 48 & 8.1 \\
\hline \multicolumn{4}{|c|}{ Family income* } \\
\hline & $1^{\text {st }}$ tertile & 268 & 45.5 \\
\hline & $2^{\text {sd }}$ tertile & 133 & 22.6 \\
\hline & $3^{\text {rd }}$ tertile & 138 & 31.9 \\
\hline \multicolumn{4}{|c|}{ Maternal schooling* } \\
\hline & $\leq 8$ years & 258 & 43.2 \\
\hline & $>8$ years & 339 & 56.8 \\
\hline \multicolumn{4}{|c|}{ Anterior open bite* } \\
\hline & Absent & 326 & 55.5 \\
\hline & Present & 261 & 44.5 \\
\hline \multicolumn{4}{|c|}{ Dental trauma } \\
\hline & Absent & 423 & 70.6 \\
\hline & Enamel fracture & 131 & 21.9 \\
\hline & Enamel and dentine fracture & 11 & 1.8 \\
\hline & $\begin{array}{l}\text { Fracture with pulp } \\
\text { involvement }\end{array}$ & 11 & 1.8 \\
\hline & Discoloration and/or fistula & 15 & 2.5 \\
\hline & Avulsion & 8 & 1.3 \\
\hline \multicolumn{4}{|c|}{ Dental caries } \\
\hline & Absent & 365 & 60.9 \\
\hline & Present & 234 & 39.1 \\
\hline
\end{tabular}

*There was data loss for the variables 'family monthly income' $(n=10)$, 'maternal schooling' ( $n=2)$ and 'anterior open bite' $(n=12)$.

Table 2. Descriptive distribution of overall and specific domains of ECOHIS and association of impact on sections and domains of ECOHIS with presence of severe dental trauma. Pelotas, Brazil $(n=599)$.

\begin{tabular}{|c|c|c|c|c|c|c|c|c|}
\hline ECOHIS domains & $\begin{array}{l}\text { Never } \\
\mathrm{n}(\%)\end{array}$ & $\begin{array}{l}\text { Hardly ever } \\
\text { n (\%) }\end{array}$ & $\begin{array}{l}\text { Occasionally } \\
\mathrm{n}(\%)\end{array}$ & $\begin{array}{l}\text { Often } \\
\mathrm{n}(\%)\end{array}$ & $\begin{array}{l}\text { Very often } \\
\mathrm{n}(\%)\end{array}$ & Mean (SD) & $\begin{array}{l}\text { Possible } \\
\text { range }\end{array}$ & Range \\
\hline \multicolumn{9}{|l|}{ Child section } \\
\hline $\begin{array}{l}\text { How often has your child... because of dental problems or } \\
\text { dental treatments? (Function Domain) }\end{array}$ & & & & & & & $0-16$ & $0-16$ \\
\hline Had difficulty eating some foods? & $506(84.5)$ & $27(4.5)$ & $47(7.8)$ & $11(1.8)$ & $8(1.4)$ & $0.31(0.80)$ & $0-4$ & $0-4$ \\
\hline Had difficulty pronouncing any words? & $558(93.2)$ & $6(1.0)$ & $15(2.4)$ & $10(1.7)$ & $10(1.7)$ & $1.18(0.7)$ & $0-4$ & $0-4$ \\
\hline
\end{tabular}


Table 2. Descriptive distribution of overall and specific domains of ECOHIS and association of impact on sections and domains of ECOHIS with presence of severe dental trauma. Pelotas, Brazil $(n=599)$.

\begin{tabular}{|c|c|c|c|c|c|c|c|c|}
\hline ECOHIS domains & $\begin{array}{l}\text { Never } \\
\mathrm{n}(\%)\end{array}$ & $\begin{array}{l}\text { Hardly ever } \\
\mathrm{n}(\%)\end{array}$ & $\begin{array}{l}\text { Occasionally } \\
\mathrm{n}(\%)\end{array}$ & $\begin{array}{l}\text { Often } \\
\text { n (\%) }\end{array}$ & $\begin{array}{l}\text { Very often } \\
\mathrm{n}(\%)\end{array}$ & Mean (SD) & $\begin{array}{l}\text { Possible } \\
\text { range }\end{array}$ & Range \\
\hline Missed preschool, daycare, or school? & $571(95.3)$ & $12(2.0)$ & $11(1.8)$ & $2(0.3)$ & $5(0.6)$ & $0.09(0.44)$ & $0-4$ & $0-4$ \\
\hline Had trouble sleeping & $529(88.4)$ & $23(3.8)$ & $35(5.8)$ & $7(1.2)$ & $5(0.8)$ & $0.22(0.68)$ & $0-4$ & $0-4$ \\
\hline Been irritable or frustrated? & $449(75.0)$ & $52(8.7)$ & $77(12.9)$ & $13(2.2)$ & $8(1.2)$ & $0.46(0.89)$ & $0-4$ & $0-4$ \\
\hline Avoided smiling or laughing when around other children? & $574(95.8)$ & $7(1.2)$ & $11(1.8)$ & $3(0.5)$ & $4(0.7)$ & $0.09(0.48)$ & $0-4$ & $0-4$ \\
\hline Avoided talking with other children? & $579(96.7)$ & $1(0.2)$ & $10(1.7)$ & $5(0.8)$ & $4(0.7)$ & $0.08(0.49)$ & $0-4$ & $0-4$ \\
\hline \multicolumn{9}{|l|}{ Family section } \\
\hline Been upset? & $479(80.0)$ & $32(5.3)$ & $55(9.2)$ & $21(3.5)$ & $12(2.0)$ & $0.42(0.94)$ & $0-4$ & $0-4$ \\
\hline Felt guilty? & $484(80.8)$ & $19(3.2)$ & $57(9.5)$ & $23(3.8)$ & $16(2.7)$ & $0.44(0.99)$ & $0-4$ & $0-4$ \\
\hline $\begin{array}{l}\text { How often ...? } \\
\text { (Family function Domain) }\end{array}$ & & & & & & & $0-8$ & $0-4$ \\
\hline $\begin{array}{l}\text { Have you or another family member taken time off from } \\
\text { work because of your child's dental problems or dental } \\
\text { treatments? }\end{array}$ & $561(93.7)$ & $13(2.2)$ & $18(3.0)$ & $6(1.0)$ & $1(0.2)$ & $0.12(0.50)$ & $0-4$ & $0-4$ \\
\hline $\begin{array}{l}\text { How often has your child had dental problems or dental } \\
\text { treatments that had a financial impact on your family? } \\
\text { (Family function) }\end{array}$ & 575 (96.0) & $9(1.5)$ & $6(1.0)$ & $7(1.2)$ & $2(0.3)$ & $0.08(0.46)$ & $0-4$ & $0-4$ \\
\hline Total ECOHIS & & & & & & $3.26(5.42)$ & $0-52$ & $0-42$ \\
\hline
\end{tabular}

ECOHIS Early Childhood Oral Health Impact Scale † The association between the impact on sections and domains of ECOHIS (ECOHIS $\geq 1)-$ Chi-square test ${ }^{*} p$-value $<0.05$.

Table 3. Association between dental trauma and OHRQoL measured by overall, prevalence, extent and intensity of ECOHIS scores in preschool children. Pelotas, Brazil $(n=599)$.

\begin{tabular}{lccc}
\hline ECOHIS score & Dental trauma absent/Mild & Severe dental trauma & $\mathrm{p}$ - value \\
\hline Extent & mean (SD) & mean (SD) & \\
\hline & $3.6(5.5)$ & $3.4(4.1)$ & 0.835 \\
\hline Prevalence & $\mathrm{n}(\%)^{* *}$ & $\mathrm{n}(\%)^{* *}$ & $\mathbf{0 . 0 4 1}$ \\
Intensity & $317(57.2)$ & $33(73.3)$ & 0.066 \\
$\quad$ & & \\
$\quad$ Hever & $237(42.8)$ & $15(33.3)$ & $3(6.7)$ \\
$\quad$ Ordly ever & $89(16.1)$ & $19(42.2)$ & $4(8.9)$ \\
$\quad$ Oecry often & $134(24.2)$ & $4(8.9)$ & \\
\end{tabular}

*Student $t$ test; ${ }^{* *}$ Chi-square test to compare proportions.

The results of the logistic regression analysis were demonstrated in table 4. The variables associated with higher ECOHIS scores after adjustments were dental trauma and dental caries. Children with dental trauma had an impact in oral health-related quality of life $110 \%$ higher than children without dental trauma (OR: 2.10, 95\% Cl 1.01-4.35). 
The final multivariate models to each ECOHIS domain are shown in table 5 . The presence of severe dental injury showed a negative impact on the symptoms (OR: 2.13,95\% Cl 1.10-4.14), psychological (OR: 2.13, 95\%IC 1.10-4.13) and family function (OR: 2.79, 95\% Cl 1.17-6.61) domains. Dental caries impact symptoms, function, psychological and parent distress domains of ECOHIS. Besides, the presence of anterior open bite was associated with self-image domain.

Table 4. Crude and adjusted analysis of association between $E C O H I S \geq 1$ and independent variables. Logistic regression analysis. Pelotas, Brazil ( $n=599)$.

\begin{tabular}{|c|c|c|c|c|c|c|}
\hline \multirow{2}{*}{ Variables } & \multicolumn{2}{|c|}{ ECOHIS impact } & \multirow{2}{*}{$\begin{array}{c}\text { Crude } \\
\text { OR }(95 \% \mathrm{Cl})\end{array}$} & \multirow{2}{*}{$p$-value } & \multirow{2}{*}{$\begin{array}{c}\text { Adjusted } \\
\text { OR }(95 \% \mathrm{Cl})\end{array}$} & \multirow{2}{*}{ p-value } \\
\hline & $\mathrm{N}$ & $\%$ & & & & \\
\hline \multicolumn{7}{|l|}{ Sex } \\
\hline Male & 182 & 61.7 & 1.00 & \multirow[t]{2}{*}{0.110} & 1.00 & \multirow[t]{2}{*}{0.351} \\
\hline Female & 168 & 55.3 & $0.77(0.55-1.06)$ & & $0.84(0.61-1.19)$ & \\
\hline \multicolumn{7}{|l|}{ Age (years) } \\
\hline 2 & 94 & 55.0 & 1.00 & \multirow{4}{*}{0.371} & \multirow{4}{*}{-} & \multirow{4}{*}{-} \\
\hline 3 & 109 & 59.6 & $1.20(0.79-1.83)$ & & & \\
\hline 4 & 114 & 57.9 & $1.12(0.74-1.70)$ & & & \\
\hline 5 & 33 & 68.8 & $1.80(0.91-3.55)$ & & & \\
\hline \multicolumn{7}{|c|}{ Family income (tertiles) } \\
\hline $1^{\text {st }}$ tertile & 163 & 60.8 & 1.00 & \multirow{3}{*}{0.053} & 1.00 & \multirow{3}{*}{0.330} \\
\hline $2^{\text {sd }}$ tertile & 85 & 63.9 & $1.14(0.74-1.75)$ & & $1.16(0.74-1.84)$ & \\
\hline $3^{\text {rd }}$ tertile & 97 & 51.6 & $0.68(0.47-1.00)$ & & $0.81(0.52-1.26)$ & \\
\hline \multicolumn{7}{|l|}{ Maternal schooling } \\
\hline$\leq 8$ years & 143 & 55.4 & 1.00 & \multirow{2}{*}{0.189} & 1.00 & \multirow{2}{*}{0.616} \\
\hline$>8$ years & 206 & 60.8 & $1.26(0.89-1.72)$ & & $1.10(0.74-1.63)$ & \\
\hline \multicolumn{7}{|l|}{ Dental trauma } \\
\hline Absent/mild & 317 & 57.2 & 1.00 & \multirow{2}{*}{0.031} & 1.00 & \multirow[t]{2}{*}{0.044} \\
\hline Severe trauma & 33 & 73.3 & $2.06(1.04-4.06)$ & & $2.10(1.01-4.35)$ & \\
\hline \multicolumn{7}{|l|}{ Dental caries } \\
\hline Absent & 181 & 49.6 & 1.00 & \multirow{2}{*}{$<0.001$} & 1.00 & \multirow{2}{*}{$<0.001$} \\
\hline Present & 169 & 72.2 & $2.64(1.85-3.76)$ & & $2.51(1.74-3.60)$ & \\
\hline \multicolumn{7}{|l|}{ Open bite } \\
\hline Absent & 182 & 55.8 & 1.00 & \multirow{2}{*}{0.106} & 1.00 & \multirow[t]{2}{*}{0.164} \\
\hline Present & 159 & 60.9 & $1.11(0.96-1.29)$ & & $1.11(0.96-1.30)$ & \\
\hline
\end{tabular}

ECOHIS Early Childhood Oral Health Impact Scale | OR odds ratio | Family Income in Brazilian currency (Real) divided in tertiles.

Table 5. Association between presence of impact in each ECOHIS domain and independent variables. Adjusted logistic regression analysis. Pelotas, Brazil $(n=599)$.

1 of 2

\begin{tabular}{|c|c|c|c|c|c|c|}
\hline Variables & $\begin{array}{l}\text { Symptons } \\
\text { OR (C195\%) }\end{array}$ & $\begin{array}{c}\text { Function } \\
\text { OR (C195\%) }\end{array}$ & $\begin{array}{l}\text { Psychological } \\
\text { OR (CI95\%) }\end{array}$ & $\begin{array}{l}\text { Self-image } \\
\text { OR (CI95\%) }\end{array}$ & $\begin{array}{l}\text { Parent distress } \\
\text { OR (C195\%) }\end{array}$ & $\begin{array}{c}\text { Family function } \\
\text { OR (C195\%) }\end{array}$ \\
\hline \multicolumn{7}{|l|}{ Sex } \\
\hline Male & 1.00 & 1.00 & 1.0 & 1.00 & 1.00 & 1.00 \\
\hline Female & $1.08(0.74-1.56)$ & $0.88(0.60-1.30)$ & $0.92(0.63-1.34)$ & $0.90(0.44-1.81)$ & $0.86(0.59-1.26)$ & $0.85(0.47-1.54)$ \\
\hline \multicolumn{7}{|l|}{ Age (years) } \\
\hline 2 & 1.00 & 1.00 & $1.00^{*}$ & 1.00 & 1.00 & 1.00 \\
\hline 3 & $0.98(0.57-1.59)$ & $0.82(0.49-1.39)$ & $0.58(0.36-0.95)$ & $1.06(0.43-2.66)$ & $1.76(1.04-2.98)$ & $0.71(0.33-1.56)$ \\
\hline 4 & $0.86(0.53-1.48)$ & $0.86(0.51-1.44)$ & $0.51(0.31-0.83)$ & $0.62(0.23-1.67)$ & $1.16(0.68-1.98)$ & $0.64(0.29-1.41)$ \\
\hline 5 & $2.13(0.88-3.86)$ & $1.29(0.62-2.70)$ & $0.35(0.16-0.80)$ & $1.31(0.39-4.44)$ & $1.64(0.77-3.49)$ & $0.67(0.20-2.24)$ \\
\hline \multicolumn{7}{|c|}{ Family income (tertiles) } \\
\hline $1^{\text {st }}$ tertile & 1.00 & 1.00 & 1.00 & 1.00 & 1.00 & 1.00 \\
\hline $2^{\text {sd }}$ tertile & $1.59(0.98-2.56)$ & $1.02(0.62-1.67)$ & $1.59(0.58-2.96)$ & $1.04(0.44-2.44)$ & $0.74(0.45-1.22)$ & $1.43(0.69-2.93)$ \\
\hline $3^{\text {rd }}$ tertile & $1.19(0.72-1.96)$ & $0.71(0.42-1.20)$ & $1.19(0.72-1.96)$ & $0.74(0.27-2.01)$ & $0.68(0.41-1.14)$ & $0.91(0.40-2.09)$ \\
\hline
\end{tabular}


Table 5. Association between presence of impact in each ECOHIS domain and independent variables. Adjusted logistic regression analysis. Pelotas, Brazil $(n=599)$.

2 of 2

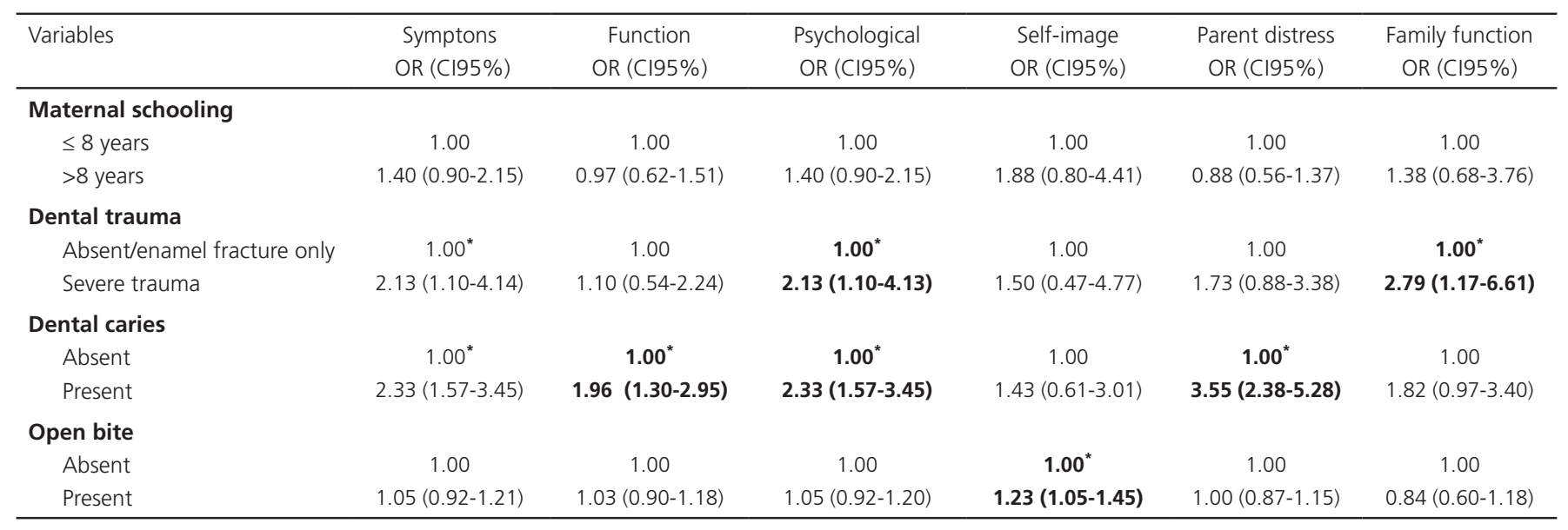

ECOHIS Early Childhood Oral Health Impact Scale | OR odds ratio | Family Income in Brazilian currency (Real) divided in tertiles. ${ }^{*}$-v-value $<0.05$.

\section{DISCUSSION}

The present study showed that children with severe traumatic dental injuries (involving at least the dentin [18] had a higher prevalence of negative impact on OHRQoL than children with no or with mild injuries. However, differences were not detected in mean scores (extent) between groups, nor in the intensity of impacts. The rationale for the exclusion of fractures limited to enamel is that these injuries do not require treatment, have a low chance of sequelae and may go unnoticed by parents. This can also explain the findings of the study.

Children were recruited during a vaccination campaign in the city of Pelotas. Since the vaccination program has a wide coverage and the centers selected encompass nearly $60 \%$ of the children attending the vaccination program, the sample can be considered representative of the population of preschool children in Pelotas [20]. Another strength of the study was the use of a validated and specific instrument to evaluate the negative impact of oral diseases on the quality of life of preschool children. Besides, dental caries and anterior open bite were included in the adjusted analysis because can act as confounders in the association between dental injuries and OHRQoL. However, this study included only the health units located in the urban part of the city and, therefore, the findings are representative of the children living in the urban region. As children living in the countryside may have different oral health conditions, further studies evaluating the rural population should be conducted.
Results are in accordance to previous study, undertaken with preschool children attending public nurseries, which showed that enamel fractures do not impact OHRQoL [9]. Previous studies have detected divergent results $[8,21]$, probably due to methodological differences. Dental trauma was previously evaluated using Andreasen criteria, that consider presence of TDI when at last one type of trauma is present [2], [3] and Glendor criteria, that classifies trauma in complicated and uncomplicated injuries [21]. In a study performed by Viegas et al. [3], the presence of TDI had no impact on quality of life of the children and their families, with exception of the cases of avulsion, which had impacted the quality of life. Abanto et al. [21] observed that children with complicated injuries were more likely to experience a negative impact. Kramer et al. [2] has adopted the same cut-off point for the ECOHIS instrument used in the present study and showed that the prevalence of any impact on OHRQoL was $70 \%$ higher in children with TDI.

Considering the different domains of the instrument, a presence the severe TDI as associated with higher frequency of impact in family function and symptoms domains. Borges et al. [22] in its meta-analysis, found that TDI caused a negative impact on OHRQoL based on overall ECOHIS, as well as scores in the child impact section, but not in the family impact section. Regarding to the family function, severe injuries can mobilize the family, which ends up expending greater attention to child, due to the severity of the lesion, reflecting in all familiar function [23], what 
justifies our findings. The presence of impact on symptoms domains indicates that injuries were associated with pain, producing a great discomfort and impact on child daily activities [4]. This reinforces the importance of excluding children with fracture restricted to enamel in the present analysis of the association between TDI and OHRQoL.

The perception of impact may be related to the living conditions of the individuals. However, in preschool children, the influence of the socioeconomic status of the family has showed divergent results. Abanto et al. [4] found that a lower family income had a negative impact on the quality of life of parents as well as Wong et al. [24], which also showed a tendency for caregivers with lower income to report greater scores. In the present study no significant relationship between family income and the impact on quality of life, as well as in studies by Kramer et al. [2] and Vollú et al. [25]. However, it should be noted that previous study with this sample, adopting the ECOHIS total score, and not the absence/presence of impact, had detected such association [20], showing that socioeconomic condition influences in the intensity of perceived impacts.

Oral diseases may represent stressful situations to child and family. The occurrence of dental trauma or caries and its consequences, such as pain, may influence the overall development of the child [26]. Knowledge about the impact of oral diseases on quality of life of children is essential for the formulation of strategies to prevent and treat these problems. The perception and attitude of parents about oral health of their children proves decisive for the occurrence of negative impact on quality of life and, in some cases, demonstrates the care expended upon to child. The perception of parents is of outmost importance, since it could influence the decisions of oral health and consumption patterns of health care [20]. For older children, ages 5 and 6, the Scale of Oral Health Outcomes for 5-year-old children (SOHO-5) which associates the child's self-report and the parents' report, can also be a satisfactory alternative to measure the quality of life related to oral health [27].

The interest in measuring the impact of oral health on quality of life of children has increased significantly due to the possibility of providing information about this population in terms of treatment needs and associated limitations, implying the need for oral health promotion. Oral diseases affect individual not only physically, but also psychologically, regardless of age. The severity of oral diseases may affect how the child grows, enjoy life, taste food and socialize. In this context, how the parents perceive and act facing oral problem in child and how health services are organized to meet the needs identified, whether preventive or treatment, are an essential dyad to maintain the quality of life of the child and family.

The measurement of clinical indicators added to an evaluation of the influence of the oral health condition on daily life is important to help develop strategies to minimize oral health problems in children, since it provides a consistent information about the impact of oral diseases on quality of life of children and their family. The identification of risk factors for impaired quality of life encourage the search for preventive dental care and helps to set adequate approaches considering the health-disease process within the context of each patient [5].

\section{CONCLUSION}

In conclusion, the results showed that the occurrence of severe dental trauma impacts on oral healthrelated quality of life of preschool children and their families, mainly on symptoms and family function domains. Results strength the importance of health promotion strategies aimed at preventing trauma in preschool children and of providing treatment for severe injuries.

\section{Collaborators}

LA PAULI participated in data collection, analyzing the data and writing of the manuscript. FS COSTA and CC AMARAL participated in data collection and writing of the manuscript. TM ARDENGHI and FF DEMARCO conceived the study and analyzed the data and ML GOETTEMS conceived the study, analyzed the data and wrote the manuscript and all authors reviewed the manuscript.

\section{REFERENCES}

1. Mendoza-Mendoza A, Iglesias-Linares A, Yanez-Vico RM, Abalos-Labruzzi C. Prevalence and complications of trauma to the primary dentition in a subpopulation of Spanish children in southern Europe Dent Traumatol. 2015;31(2):144-149. https://dx.doi.org/10.1111/edt.12147

2. Kramer PF, Feldens CA, Ferreira SH, Bervian J, Rodrigues PH, Peres MA. Exploring the impact of oral diseases and disorders on quality of life of preschool children. Community Dent Oral Epidemiol. 2013;41(4):327-335. https://dx.doi.org/10.1111/ cdoe. 12035 
3. Viegas CM, Paiva SM, Carvalho AC, Scarpelli AC, Ferreira FM, Pordeus IA. Influence of traumatic dental injury on quality of life of Brazilian preschool children and their families. Dent Traumatol. 2014;30(5):338-347. https://dx.doi.org/10.1111/ edt. 12091

4. Abanto J, Tello G, Bonini GC, Oliveira LB, Murakami C, Bonecker M. Impact of traumatic dental injuries and malocclusions on quality of life of preschool children: a population-based study. Int J Pediatr Dent. 2015;25(1):18-28. https://dx.doi.org/10.1111/ipd.12092

5. Gomes MC, Pinto-Sarmento TC, Costa EM, Martins CC, Granville-Garcia AF, Paiva SM. Impact of oral health conditions on the quality of life of preschool children and their families: a cross-sectional study. Health Qual Life. 2014;12:55. https:// dx.doi.org/10.1186/1477-7525-12-55

6. Firmino RT, Gomes MC, Vieira-Andrade RG, Martins CC, Paiva SM, Granville-Garcia AF. Case-control study examining the impact of oral health problems on the quality of life of the families of preschoolers. Braz Oral Res. 2016;30(1):121. https://dx.doi.org/10.1590/1807-3107BOR-2016.vol30.0121

7. Vieira-Andrade RG, Siqueira MB, Gomes GB. Impact of traumatic dental injury on the quality of life of young children: a case-control study. Int Dent J. 2015;65(5):261-268. https:// dx.doi.org/10.1111/idj.12182

8. Siqueira $M B$, Firmino $R T$, Clementino MA, Martins $C C$, Granville-Garcia AF, Paiva SM. Impact of traumatic dental injury on the quality of life of Brazilian preschool children. Int J Environ Res Public Health. 2013;10(12):6422-6441. https:// dx.doi.org/10.3390/ijerph10126422

9. Feldens CA, Day P, Borges TS, Feldens EG, Kramer PF. Enamel fracture in the primary dentition has no impact on children's quality of life: implications for clinicians and researchers. Dent Traumatol. 2016;32(2):103-109. https://dx.doi.org/10.1111/ edt.12222

10. Rasmusson CG, Koch G. Assessment of traumatic injuries to primary teeth in general practise and specialized paediatric dentistry. Dent Traumatol. 2010;26(2):129-132. https://dx.doi. org/10.1111/j.1600-9657.2009.00862.x

11. Viegas CM, Scarpelli AC, Carvalho AC, Ferreira Fde $M$, Pordeus IA, Paiva SM. Impact of traumatic dental injury on quality of life among Brazilian preschool children and their families. Pediatr Dent. 2012;34(4):300-306.

12. Abanto J, Paiva SM, Raggio DP, Celiberti P, Aldrigui JM, Bonecker $\mathrm{M}$. The impact of dental caries and trauma in children on family quality of life. Community Dent Oral Epidemiol. 2012;40(4):323-331. https://dx.doi.org/10.1111/ j.1600-0528.2012.00672.x

13. Scarpelli AC, Oliveira BH, Tesch FC, Leao AT, Pordeus IA, Paiva SM. Psychometric properties of the Brazilian version of the Early Childhood Oral Health Impact Scale (B-ECOHIS). BMC Oral Health. 2011;11:19. https://dx.doi.org/10.1186/14726831-11-19

14. Martins-Junior PA, Ramos-Jorge J, Paiva SM, Marques LS, Ramos-Jorge ML. Validations of the Brazilian version of the Early Childhood Oral Health Impact Scale (ECOHIS). Cad Saude Publica. 2012;28(2):367-374. https://dx.doi.org/10.1590/S010 2-311x2012000200015
15. Pahel BT, Rozier RG, Slade GD. Parental perceptions of children's oral health: the Early Childhood Oral Health Impact Scale (ECOHIS). Health Qual Life Out. 2007;5:6. https://dx.doi. org/10.1186/1477-7525-5-6

16. World Health Organization. Oral health surveys: basic methods. 5 ed. Geneva: World Health Organization; 2013.

17. O'Brien M. Children's dental health in the United Kingdom. HMSO; 1994.

18. Sgan-Cohen HD, Megnagi G, Jacobi Y. Dental trauma and its association with anatomic, behavioral, and social variables among fifth and sixth grade schoolchildren in Jerusalem. Community Dent Oral Epidemiol. 2005;33(3):174-180,2005. https://dx.doi.org/10.1111/j.1600-0528.2005.00202.x

19. Moyers R. Ortodontia. $4^{a}$ ed. Rio de Janeiro: Guanabara Koogan; 1991

20. Goettems ML, Ardenghi TM, Romano AR, Demarco FF, Torriani DD. Influence of maternal dental anxiety on oral health-related quality of life of preschool children. Qual Life Res. 2011;20(6):951-959. https://dx.doi.org/10.1111/j.16000528.2012.00694.x

21. Abanto J, Tsakos G, Paiva SM, Carvalho TS, Raggio DP, Bönecker M. Impact of dental caries and trauma on quality of life among 5-to 6-year-old children: perceptions of parents and children. Community Dent Oral Epidemiol. 2014;42(5):385-394. https://dx.doi.org/10.1111/cdoe.12099

22. Borges TS, Vargas-Ferreira F, Kramer PF, Feldens CA. Impact of traumatic dental injuries on oral health-related quality of life of preschool children: a systematic review and meta-analysis. PLoS ONE. 2017;12(2). https://dx.doi.org/10.1371/journal. pone.0172235

23. Aldrigui JM, Abanto J, Carvalho TS, et al. Impact of traumatic dental injuries and malocclusions on quality of life of young children. Health Qual Life. 2011;Out9:78.https://dx.doi.org/10. 1186/1477-7525-9-78.

24. Wong HM, McGrath CP, King NM, Lo EC. Oral health-related quality of life in Hong Kong preschool children. Caries Res. 2011;45(4):370-376. https://dx.doi.org/10.1159/000330231

25. Vollú AL, Costa MDEPR, Maia LC, Fonseca-Gonçalves A. Evaluation of Oral Health-Related Quality of Life to Assess Dental Treatment in Preschool Children with Early Childhood Caries: A Preliminary Study. J Clin Pediatr Dent. 2018;42(1):3744.https://dx.doi.org/10.17796/1053-4628-42.1.7

26. Bhatia SK, Maguire SA, Chadwick BL. Characteristics of child dental neglect: a systematic review. J Dent. 2014;42(3):229239. https://dx.doi.org/10.1016/j.jdent.2013.10.010

27. Abanto J, Tsakos L, Paiva SM, Goursand D, Raggio DP, Bonecker M. Cross-cultural adaptation and psychometric properties of the Brazilian version of the scale of oral health outcomes for 5-year-old children (SOHO-5). Health Qual Life Outcomes. 2013;11:16. https://dx.doi.org/10.1186/1477-75 25-11-16

Received on: 17/3/2019 Final version resubmitted on: 17/4/2019 Approved on: 17/5/2019 